(c) American Dairy Science Association, 2005.

\title{
Altering the Fatty Acids in Milk Fat by Including Canola Seed in Dairy Cattle Diets
}

\author{
M. W. Chichlowski, ${ }^{\star}$ J. W. Schroeder, C. S. Park, W. L. Keller, and D. E. Schimek \\ Department of Animal and Range Sciences, North Dakota State University, Fargo 58105
}

\begin{abstract}
The objective was to evaluate the effects of feeding ground canola seed on the fatty acid profile, yield, and composition of milk from dairy cows. Twenty-four multiparous Holstein cows $(548.3 \pm 11.9 \mathrm{~kg}$ body weight and $28 \pm 9 \mathrm{~d}$ in lactation) were randomly assigned to 1 of 2 treatments: Control (CON) or ground canola seed treatment (GCS) with 14\% [of diet dry matter $(\mathrm{DM})]$ of the total ration as ground canola seed containing 34\% lipid. Diets contained 20\% crude protein, but varied in net energy as a result of fat content differences of $2.5 \%$ and $6.4 \%$ (DM) for CON and GCS, respectively. Diets were composed of corn, corn silage, alfalfa (50:50 ground hay and haylage, DM basis), soybean and blood meal, and vitamins and minerals. Mechanically extruded canola meal was used in the CON diet to adjust for the protein from canola seed in the GCS diet. Cows were housed in tie-stalls and fed and milked twice daily for $10 \mathrm{wk}$. The inclusion of ground canola seed did not alter DM intake, weight gain, or body condition score of cows. Milk fat from GCS cows had greater proportions of long-chain fatty acids ( $\geq 18$ carbons) and a lower ratio of n-6 to n-3 fatty acids. Feeding GCS reduced the proportion of short- and medium-chain fatty acids. Milk fat from cows fed GCS had a greater proportion of vaccenic acid and tended to have a higher proportion of cis-9,trans-11 conjugated linoleic acid. Actual and 3.5\% fat-corrected milk yields were similar between treatments. The milk fat and protein percentages were lower for GCS cows, but total yield of these components was similar between treatments. Milk urea nitrogen was lower and serum urea nitrogen tended to be lower in cows fed canola seed. Serum glucose, insulin, and nonesterified fatty acids were not altered, but serum triglycerides were higher in GCS cows. Ammonia and total volatile fatty acids tended to be lower in ruminal fluid from GCS cows;
\end{abstract}

Received February 17, 2005.

Accepted May 19, 2005.

Corresponding author: J. W. Schroeder; e-mail: jschroed@ndsuext. nodak.edu.

*Current address: North Carolina State University, Department of Poultry Science, Box 7608, Raleigh, NC 27695. rumen $\mathrm{pH}$ was unchanged. Feeding canola seed to lactating dairy cows resulted in milk fat with higher proportions of healthful fatty acids without affecting milk yield or composition of milk.

(Key words: canola seed, fatty acid, conjugated linoleic acid, dairy cow)

Abbreviation key: BUN = blood urea nitrogen, CLA = conjugated linoleic acid, $\mathbf{C O N}=$ control, $\mathbf{G C S}=$ ground canola seed treatment, PUFA = polyunsaturated fatty acids, TVA $=$ vaccenic acid .

\section{INTRODUCTION}

Conjugated linoleic acid (CLA) refers to the group of positional and geometrical isomers of linoleic acid (cis-9,cis-12 octadecadienoic acid) with conjugated double bonds. Two CLA isomers, cis-9,trans-11 and trans-10,cis-12, have been reported as the most biologically active (Bauman et al., 1999) with more than $90 \%$ of the CLA in milk as cis-9,trans-11 isomer. Numerous beneficial physiological effects have been attributed to CLA, from changes in body composition (Gaullier et al., 2004) to lower insulin resistance associated with cardiovascular disease (Aminot-Gilchrist and Anderson, 2004). Emerging interest includes observed inhibition of carcinogenesis even at extremely low dietary concentrations.

Food products from ruminants are the major dietary source of CLA for humans. The content of CLA in fat from ruminant-derived foods is dependent on the ruminal production of both CLA and vaccenic acid (TVA) and on the tissue activity of $\Delta^{9}$-desaturase (Bauman et al., 1999). The concentration of CLA in milk is increased by varying the level and sources of unsaturated fats in the dairy cow diet (Dhiman et al., 1999). Canola seed is readily available in the northern United States and Canada, and it is an excellent source of dietary fat high in essential fatty acids and protein for dairy animals. We hypothesized that a diet containing ground canola seed would provide linoleic and linolenic acids stimulating TVA and CLA production in the rumen. Our objective was to evaluate the effects of feeding ground canola seed on the fatty acid profile of milk fat and on the yield and composition of milk from dairy 
cows using diets with protein derived from canola. Increasing specific unsaturated fatty acids, namely cis9,trans-11 CLA and linoleic acid, in milk fat may enhance consumer acceptance of milk and the healthful benefits associated with a reduction in trans fatty acids in dairy products.

\section{MATERIALS AND METHODS}

\section{Animals, Treatments, and Sampling}

Twenty-four lactating Holstein cows (548.3 \pm 11.9 $\mathrm{kg} \mathrm{BW}, 30 \pm 2$ mo of age, and $28 \pm 9$ DIM) were blocked by age, stage of lactation, and milk production. Because of facility limitations, cows were allotted to 1 of 2 replicates (one conducted in the fall and the other the following spring). In both replicates, 12 cows were assigned to 1 of 2 treatments: Control (CON) or ground canola seed treatment (GCS). Cows in both treatments were fed a similar basal diet, except for the added canola seed, in a completely randomized design. The inherent dietary protein difference between GCS and CON was minimized by adjusting dietary protein with canola meal for isonitrogenous (19\% of diet DM) rations. The addition of $3.9 \%$ fat from canola seed represents 6.4 (GCS) vs. $2.5 \%(\mathrm{CON})$ of ration $\mathrm{DM}$ as fat. Unlike some other oilseeds (e.g., soybeans), canola has a very refractory seed coat that is resistant to degradation in both the rumen and small intestine of cattle unless it undergoes some form of processing (Khorasani et al., 1992), such as grinding. The canola seed was ground separately through a 1/2-half circle design, $63.5-\mathrm{cm}$ (diameter) hammer mill equipped with a 10hp motor and an $28-\times 101.6-\mathrm{cm}$ screen with $0.24-\mathrm{cm}$ (6/64 inch) openings, operated at $1800 \mathrm{rpm}$ (hammer tip-speed was $3889 \mathrm{~m} / \mathrm{min}$ ). Fresh water was available at all times. Feed was mixed daily (at $1200 \mathrm{~h}$ in the fall study and $0600 \mathrm{~h}$ in the spring study) and delivered twice daily at 0700 and $1500 \mathrm{~h}$ in amounts to ensure a 5 to $10 \%$ refusal on an as-fed basis. Cows were housed and handled in accordance with protocols approved by the University Animal Care and Use Committee using individual tie-stalls at the North Dakota State University Dairy Research Center.

Cows were weighed for 3 consecutive days and the weights averaged at the onset and every $3 \mathrm{wk}$ (wk 3 , 6 , and 9) of the 10-wk trial. Each cow was also assigned a BCS on the first of each 3 -d weigh period. Cows were scored on a 5 -point scale where $1=$ emaciated and $5=$ overly fat (Wildman et al., 1982). Both replications (fall and spring) used the same diet formulation comprised of stored quantities of the same feeds, except corn. The composition and chemical analysis of the
Table 1. Ingredients and chemical composition of experimental diets for lactating dairy cows. ${ }^{1}$

\begin{tabular}{|c|c|c|}
\hline Item & $\mathrm{CON}$ & GCS \\
\hline Ingredients & \multicolumn{2}{|c|}{$-\%$ of $\mathrm{DM}$} \\
\hline Alfalfa hay and haylage (50:50) & 24.0 & 24.0 \\
\hline Corn silage & 28.0 & 28.0 \\
\hline Soybean meal & 7.0 & 7.0 \\
\hline Blood meal, ring-dried ${ }^{2}$ & 2.0 & 2.0 \\
\hline Vitamin and mineral premix ${ }^{3}$ & 0.2 & 0.2 \\
\hline Sodium chloride & 0.1 & 0.1 \\
\hline Sodium bicarbonate & 0.7 & 0.7 \\
\hline Magnesium oxide & 0.4 & 0.4 \\
\hline Limestone & 0.3 & 0.3 \\
\hline Canola seed, ground & 0.0 & 14.0 \\
\hline Canola meal, mechanically extracted & 13.8 & 0.0 \\
\hline Corn, ground & 23.5 & 23.3 \\
\hline \multicolumn{3}{|l|}{ Chemical composition } \\
\hline $\mathrm{NE}_{\mathrm{L}}, \mathrm{Mcal} / \mathrm{kg}^{4}$ & 1.6 & 1.8 \\
\hline $\mathrm{CP}, \%$ & 20.3 & 19.5 \\
\hline $\mathrm{ADF}, \%$ & 22.5 & 20.8 \\
\hline $\mathrm{NDF}, \%$ & 37.2 & 35.7 \\
\hline Ether extract, \% & 2.5 & 6.4 \\
\hline
\end{tabular}

${ }^{1} \mathrm{CON}=$ Control; GCS = ground canola seed treatment.

${ }^{2}$ Experiment conducted before the issues with bovine blood meal for ruminant use.

${ }^{3}$ Contained $2,800,000$ IU of vitamin A; 771,000 IU of vitamin D; and 13,500 IU of vitamin E per kilogram.

${ }^{4}$ Estimated using $\mathrm{NE}_{\mathrm{L}}$ values for feedstuffs from NRC (2001).

experimental diets are shown in Table 1. Ground canola seed or canola meal were blended into their respective GCS or CON diets formulated (NRC, 2001) to contain $19.0 \% \mathrm{CP}$ and $1.74 \mathrm{Mcal} / \mathrm{kg} \mathrm{NE}$ for Holstein cows estimated to weigh $590 \mathrm{~kg}$, consume $22.7 \mathrm{~kg} / \mathrm{d}$ of DM, average 34 mo of age, at 40 DIM, targeted to produce $40.8 \mathrm{~kg}$ of milk containing $3.5 \%$ fat, $3.0 \%$ protein for cows with a 2.5 average BCS. The GCS diet contained ground canola seed fed at 14\% (DM of diet basis) or $1.26 \mathrm{~kg} / \mathrm{d}$. No adjustment was made to the CON diet to compensate for the added fat from canola seed. Rumen-degradable protein, metabolizable protein, and essential AA for diets were calculated using the NRC (2001) computer model program for predicting nutrient requirements. The TMR and orts were sampled daily for 3 consecutive days, composited, and frozen for each collection during wk 3,6 , and 9 . The DM content of feed ingredients was also determined on a similar schedule by drying for $48 \mathrm{~h}$ at $55^{\circ} \mathrm{C}$ in a forced-air oven. Dietary formulations were adjusted (if necessary) to account for changes in ingredient DM content.

Similarly, oven-dried feeds were ground through a Wiley mill (2-mm screen; Arthur H. Thomas, Philadelphia, PA). Feed ingredients were analyzed for DM (AOAC procedure 930.15, 1997); CP, Kjeldahl procedure (Kjeltec 1030, Herndon, VA; AOAC procedure 984.13, 1997); ether extract (AOAC procedure 945.16, 1997); $\mathrm{Ca}$ (AOAC procedure 968.08, 1997); and $\mathrm{P}$ 
(AOAC procedure 965.17, 1997). Acid detergent fiber and NDF were analyzed with the Ankom fiber analysis unit (Ankom Technology, Fairport, NY) using the reagents in Van Soest et al. (1991). The $\mathrm{NE}_{\mathrm{L}}$ content of each TMR was estimated using equations from NRC (2001).

Cows were milked twice daily at 0700 and $1500 \mathrm{~h}$, and milk weights were recorded using DHIA-certified Perfection 3000 milk meters and Agri-Term data management software (Bou-Matic LLC, Madison, WI). Energy-corrected milk was determined using the formula $\mathrm{ECM}=(0.3246 \times \mathrm{kg}$ milk $)+(12.86 \times \mathrm{kg}$ fat $)+(7.04 \times$ $\mathrm{kg}$ protein). Composite milk samples were obtained from 2 consecutive a.m. and p.m. milkings before the start of the trial and every $2 \mathrm{wk}$ for the duration of the experiment. An aliquot of milk was frozen for subsequent fatty acid analysis; one Broad Spectrum Microtabs II (D \& F Control Systems, Dublin, CA) tablet was added to $40 \mathrm{~mL}$ of milk before shipment to the Heart of America DHIA laboratory (Manhattan, KS). Milk was analyzed for fat, protein, and lactose (AOAC procedure 972.16, 1997) using a Bentley 2000 with a B filter (Bentley Instruments, Chaska, MN) calibrated to quantify midinfrared absorption peak wavebands in the 2 to $15 \mu \mathrm{m}$ range; for SCC by laser-based flow cytometry (AOAC procedure 978.26, 1997) using a Somacount 500 (Bentley Instruments) with ethidium bromide staining and fluorescence characteristics; and for MUN with a Chemspec 150, (Bentley Instruments) using colorimetric procedures and urease/Berthelot reagent (Chaney and Marbach, 1962).

Blood samples were collected $3 \mathrm{~h}$ postfeeding via coccygeal venipuncture into SST gel and clot activator Vacutainers (Becton Dickinson, Franklin Lakes, NJ) immediately before the onset of the study and on $\mathrm{d} 21$, 42 , and 63. Blood was centrifuged at $1500 \times g$ for 30 min, and serum was stored at $-20^{\circ} \mathrm{C}$ until analyses for insulin (Coat-A-Count; Diagnostic Products Corporation, Los Angeles, CA) by solid-phase radioimmunoassay (Marschner et al., 1974); glucose (Glucose Infinity Reagent; Sigma Chemical Co., St. Louis, MO) based on hexokinase/glucose-6-phosphate dehydrogenase procedures described in Farrance (1987); blood urea nitrogen (BUN) (procedure 640; Sigma Chemical Co.) based on urease/Berthelot reagent (Chaney and Marbach, 1962); triglycerides (Infinity Triglyceride Reagent; Sigma Chemical Co.) based on lipase/glycerol kinase/glycerol oxidase/peroxidase procedures modified by Fossati and Prencipe (1982) and McGowan et al. (1983); and NEFA (NEFA C; WAKO Chemical USA, Inc., Richmond, VA) based on enzymatic procedures of Jeevanandam et al. (1989). Glucose, NEFA, and triglyceride assays were adapted to 96 -well microtiter plates.
Ruminal fluid was collected before the onset and on d 69 of the experiment $3 \mathrm{~h}$ postfeeding via stomach pump according to procedures in Dirksen and Smith (1987). In brief, following $\mathrm{pH}$ determination, samples were transported to the laboratory on ice. Ruminal fluid was acidified with $25 \%$ (wt/vol) metaphosphoric acid according to Erwin et al. (1961) and frozen until analyses of ammonia by a colorimetric procedure (modified procedure 640, urease hydrolysis omitted, Sigma Chemical Co.) and volatile fatty acids (VFA). Volatile fatty acids were determined by a procedure of Erwin et al. (1961); a gas chromatograph (5890 Hewlett Packard, Rolling Meadows, IL) with a capillary column (Nukol fused silica capillary column $15 \mathrm{~m} \times 0.53 \mathrm{~mm} \times 0.5$ $\mu \mathrm{m}$ film thickness; Supelco, Bellefonte, PA) was used. Conditions were as follows: the injector and detector temperatures were 250 and $260^{\circ} \mathrm{C}$, respectively; the temperature program was a steady increase from 70 to $190^{\circ} \mathrm{C}$ for a total run time of $7.5 \mathrm{~min}$.

\section{Fatty Acid Analysis}

Isomers of CLA and the fatty acid profiles of milk, canola seed, and experimental diets and forages were determined by gas chromatography. Feed and frozen milk samples were shipped to Virginia Polytechnic Institute and State University in Blacksburg, VA (laboratory of J. Herbein) for analysis using the following procedures. Feed samples were further ground in a Cyclotec mill (1-mm screen; Tecator 1093, Hoganas, Sweden). Milk fat was separated by centrifugation $(8000 \times g ; 45 \mathrm{~min})$, and whey was removed by vacuum aspiration leaving the fat layer. Lipids were extracted with chloroform:methanol $(2: 1 \mathrm{vol} / \mathrm{vol}$; Folch et al., 1957). Methyl esters of fatty acids from feed and milk were prepared by the transesterification procedure of Park and Goins (1994). The internal standard used was 10-undecenoate (Nu-Check Prep, Elysian, MN). The methyl esters of fatty acids were injected by autosampler into an Agilent 6890N gas chromatograph fitted with a flame-ionization detector (Agilent Technologies, Palo Alto, CA). A $100-\mathrm{m} \times 0.25-\mathrm{mm} \times 0.2-\mu \mathrm{m}$ film thickness fused silica column (CP-Sil 88; Varian, Inc., Palo Alto, CA) was used to separate fatty acid methyl esters. Gas chromatography conditions were as follows: the injection volume was $0.5 \mu \mathrm{L}$, a split injection was used (70:1 vol/vol); ultrapure hydrogen was the carrier gas; and the injector and detector temperatures were 250 and $300^{\circ} \mathrm{C}$, respectively. The initial temperature was $70^{\circ} \mathrm{C}$ (held for $1 \mathrm{~min}$ ), increased by $5^{\circ} \mathrm{C}$ per min to $100^{\circ} \mathrm{C}$ (held for $3 \mathrm{~min}$ ), increased by $10^{\circ} \mathrm{C}$ per min to $175^{\circ} \mathrm{C}$ (held for $40 \mathrm{~min}$ ), and then increased by $5^{\circ} \mathrm{C}$ per min to $220^{\circ} \mathrm{C}$ (held for $19 \mathrm{~min}$ ) for a total run time of $86.5 \mathrm{~min}$. Data integration and 
quantification were accomplished with Agilent 3365 ChemStation (Agilent Technologies) software.

\section{Statistical Analyses}

The statistical model used for all analyses included the main effects of diet, season, period, and their interactions. Because season had no effect, these data were combined and analyzed using the MIXED procedures of SAS (Littell et al., 1996) with cow as the experimental unit. Effects of treatment were tested using the random effects of cow as the error term. Least square means were separated by least significant difference when 1 -way ANOVA $F$-tests were significant at $P<$ 0.05 .

\section{RESULTS AND DISCUSSION}

\section{Dietary Composition}

Complete diets (Table 1) were formulated for Holstein cows averaging $40.8 \mathrm{~kg}$ of milk/d with $20 \% \mathrm{CP}$ (of diet DM). The respective GCS and CON TMR analyses averaged $19.5 \%$ and $20.3 \% \mathrm{CP}$ and were estimated at 1.76 and $1.61 \mathrm{Mcal} / \mathrm{kg} \mathrm{NE}_{\mathrm{L}}$ using $\mathrm{NRC}$ (2001) equations. The resulting GCS TMR was slightly lower in $\mathrm{ADF}$ and NDF. Because both diets met or exceeded energy and protein requirements, little difference was expected in milk yield or composition. The dietary protein level of CON was adjusted using canola meal to reduce inherent differences in the AA profile when using other protein sources in the diet. It should be noted that the canola meal was not derived from the same cultivar as the canola seed, allowing disparity in protein degradability and contributing to potential differences between diets in milk production. Furthermore, the toasting of canola seed during the desolventizing process can alter protein degradability in the by-product meal resulting in a different relative proportion of RDP to RUP in the diet. The larger proportion of undegradable protein in CON provided 0.114 $\mathrm{kg} / \mathrm{d}$ of additional RUP. Although comparatively minor, this excess may have contributed to reduced milk yield associated with the added metabolic energy required to recycle and excrete circulating urea. Nonetheless, our estimates for RDP were similar between diets, supplying $0.98 \mathrm{~kg} / \mathrm{d}$ more RDP than required. The CON diet contained $815.06 \mu \mathrm{g}$ of fatty acid/mg (2.5\% of diet DM) of fat, whereas the GCS diet contained $917.89 \mu \mathrm{g}$ of fatty acid/mg (6.4\% of diet DM) of fat, resulting in $3.9 \%$ more dietary fat in CON (Table 1). Consequently, the GCS ration had $0.15 \mathrm{Mcal} / \mathrm{kg}$ more $\mathrm{NE}_{\mathrm{L}}$ than the $\mathrm{CON}$ ration.

Canola seed is an excellent source of oleic acid and the forages used had moderate levels of monoenoic fatty acids (Table 2); the GCS diet was higher in oleic acid $\left(\mathrm{C}_{18: 1}\right)$ than the CON diet. Oleic acid was the predominant fatty acid in both rations and was more concentrated in the GCS TMR than in the CON TMR (271.63 vs. $157.51 \mu \mathrm{g}$ of fatty acid/mg of fat, respectively). The GCS ration contained more linoleic acid (cis-9,cis-12 $\mathrm{C}_{18: 2}$ ), the dienoic fatty acid precursor of CLA with demonstrated biological value for ruminal biohydrogenation via the isomerization of cis-9,cis-12 $\mathrm{C}_{18: 2}$ in the presence of the enzyme $\Delta^{12}$-cis, $\Delta^{11}$-trans isomerase to produce the cis-9,trans-11 CLA isomer (Baumgard et al., 2000).

\section{Intake, BW, and Ruminal Measures}

Fat, especially from sources high in unsaturated fatty acids, can reduce fiber digestibility, alter the ratio of ruminal acetate to propionate, and lower intake, when total dietary level exceeds 6 to $7 \%$ DM (NRC, 2001). Variation normally depends on dietary factors that alter the rumen environment (e.g., forage-to-concentrate ratio and DM intake). The DM intake was not different between CON and GCS (21.5 and 21.2; respectively) even with the addition of $3.9 \%$ dietary fat from canola seed. The diet had a 52:48 forage-toconcentrate ratio. No differences between treatments were apparent in average BW (564.6 vs. $557.1 ; P=$ $0.77)$, BW gain (34.2 vs. $23.7 ; P=0.84)$, and BCS (2.6 vs. $2.6 ; P=0.87)$.

Ruminal $\mathrm{pH}$ and VFA data provide further insight into digestive properties associated with a diet. The $\mathrm{pH}$ was unaffected by treatment; however, ruminal ammonia tended $(P=0.10)$ to be lower for GCS than for CON cows (Table 3). The addition of ground canola seed tended to decrease the total concentration of ruminal VFA $(P=0.07)$, results which are in agreement with others (Aldrich et al., 1997) who reported lower VFA concentrations after feeding canola seed to dairy cows. Although ruminal propionate was not affected, Schauff and Clark (1992) found that molar percentages of ruminal propionate tend to be lower in cows on high-fat rations. The addition of fat partially replaces the nonstructural carbohydrates in the ration. The result is reduced fermentable carbohydrate available for VFA production, which can cause a decrease in both the proportion of propionate and the total VFA concentration in the rumen. Valerate and isovalerate were lower ( $P=0.04$ and $P=0.03$, respectively) in ruminal fluid from cows on the GCS diet, but no differences were apparent for butyrate. The canola seed in GCS did not appear to alter ruminal fermentation characteristics or absorption. Assuming all VFA contribute equally to ruminal acid load, and acknowledging the significant buffering capacity of the rumen, the 
Table 2. Fatty acid composition of experimental diets, canola seed, alfalfa hay, alfalfa haylage, and corn silage for lactating dairy cows. ${ }^{1}$

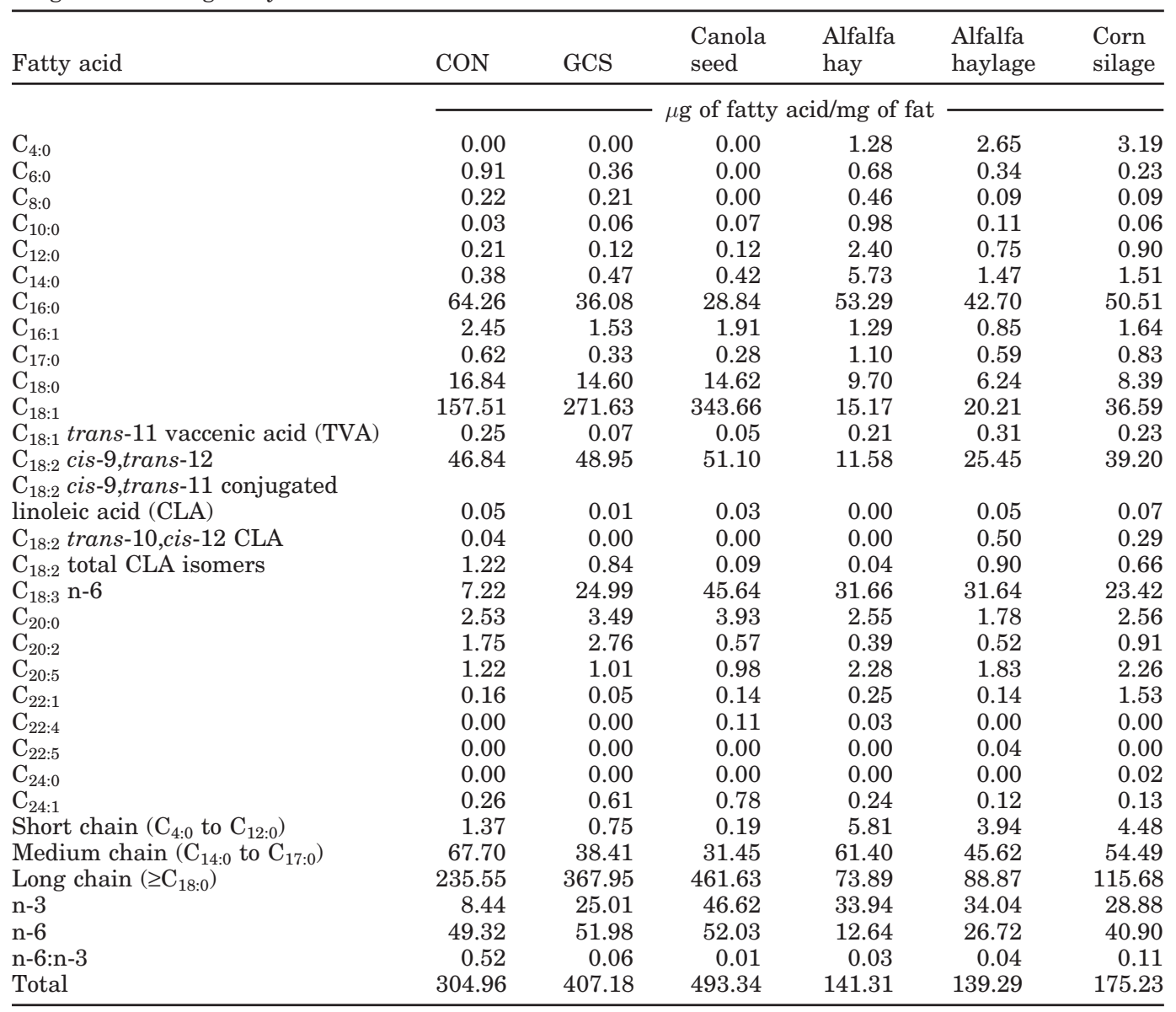

${ }^{1} \mathrm{CON}=$ Control; GCS $=$ ground canola seed treatment.

changes in VFA proportions do not appear sufficient to alter ruminal $\mathrm{pH}$. Because feed intake and ruminal acetate-to-propionate ratios were similar, we assume

Table 3. Least squares means of volatile fatty acids (VFA), $\mathrm{pH}$, and ammonia from ruminal fluid for lactating dairy cows fed a diet containing $14 \%$ (of diet DM) ground canola seed. ${ }^{1}$

\begin{tabular}{lrrrr}
\hline Item & CON & GCS & SEM $^{2}$ & $P^{3}$ \\
\hline VFA, \% & & & & \\
$\quad$ Acetate & 61.00 & 60.90 & 0.54 & 0.99 \\
Propionate & 19.10 & 20.35 & 0.65 & 0.19 \\
Butyrate & 11.22 & 10.91 & 0.21 & 0.30 \\
Isobutyrate & 2.39 & 2.10 & 0.13 & 0.13 \\
Valerate & 3.02 & 2.73 & 0.09 & 0.04 \\
Isovalerate & 3.25 & 2.90 & 0.11 & 0.03 \\
Acetate:propionate & 3.32 & 3.18 & 0.11 & 0.37 \\
Total VFA, mM & 121.41 & 108.77 & 4.79 & 0.07 \\
pH & 6.90 & 6.84 & 0.09 & 0.71 \\
Ammonia, m $M$ & 11.57 & 9.82 & 0.74 & 0.10 \\
\hline
\end{tabular}

${ }^{1} \mathrm{CON}=$ Control; GCS $=$ ground canola seed treatment.

${ }^{2}$ Standard error of the mean, $\mathrm{n}=12$.

${ }^{3}$ Probability, significance level of $F$-test for equality. fermentation was not inhibited due to properties associated with ground canola seed in this diet.

\section{Milk Yield, Milk Composition, and Blood Measures}

Milk composition is reported in Table 4. Lactose percentage and yield, SCC, and yield of actual and 3.5\% FCM were not different. Protein percentages were lower $(P=0.03)$ in milk from GCS cows, yet total yield of these milk components were not different. Fat percentage was lower in milk from GCS cows than in milk from $\mathrm{CON}$ cows $(P=0.02)$; but when corrected for total yield of milk fat, the difference was negligible. Aldrich et al. (1997) reported that feeding lactating dairy cow diets supplemented with canola ( $11.2 \%$ of DM) maintained or increased milk fat percentages. In the present study, when milk yield was adjusted for fat and protein percentages, the GCS cows produced less energy-corrected milk. Diets that are high-concentrate, low-fiber, or supplemented with plant oils can cause a reduction in milk fat secretion in dairy cows. De- 
Table 4. Least squares means of milk yield and composition and serum urea nitrogen and triglycerides for lactating dairy cows fed a diet containing $14 \%$ (of diet DM) ground canola seed. ${ }^{1}$

\begin{tabular}{|c|c|c|c|c|}
\hline Item & $\mathrm{CON}$ & GCS & $\mathrm{SEM}^{2}$ & $P^{3}$ \\
\hline \multicolumn{5}{|l|}{ Milk yield } \\
\hline Actual, kg/d & 34.9 & 35.0 & 1.31 & 0.96 \\
\hline $3.5 \% \mathrm{FCM}^{4}{ }^{4} \mathrm{~kg} / \mathrm{d}$ & 38.1 & 36.4 & 1.58 & 0.45 \\
\hline Energy-corrected milk, ${ }^{5} \mathrm{~kg} / \mathrm{d}$ & 44.1 & 41.7 & 0.67 & 0.01 \\
\hline \multicolumn{5}{|l|}{ Milk composition } \\
\hline Fat, \% & 4.0 & 3.7 & 0.10 & 0.02 \\
\hline Fat yield, kg/d & 1.4 & 1.3 & 0.06 & 0.27 \\
\hline Protein, \% & 2.9 & 2.7 & 0.10 & 0.03 \\
\hline Protein yhield, kg/d & 0.9 & 0.9 & 0.03 & 0.19 \\
\hline Lactose, \% & 4.9 & 4.8 & 0.10 & 0.17 \\
\hline Lactose yield, kg/d & 1.7 & 1.7 & 0.06 & 0.65 \\
\hline MUN, mM & 14.9 & 12.9 & 0.47 & 0.01 \\
\hline $\mathrm{SCC}, \times 1000$ cells $/ \mathrm{mL}$ & 138.6 & 162.6 & 58.90 & 0.77 \\
\hline \multicolumn{5}{|l|}{ Serum analysis } \\
\hline Urea nitrogen, $\mathrm{m} M$ & 14.6 & 13.4 & 0.45 & 0.08 \\
\hline Triglycerides, mg/dL & 12.0 & 13.7 & 0.45 & 0.01 \\
\hline \multicolumn{5}{|c|}{${ }^{1} \mathrm{CON}=$ Control; GCS = ground canola seed treatment. } \\
\hline \multicolumn{5}{|c|}{${ }^{2}$ Standard error of the mean, $\mathrm{n}=12$} \\
\hline \multicolumn{5}{|c|}{${ }^{3}$ Probability, significance level of $F$-test for equality. } \\
\hline \multicolumn{5}{|c|}{${ }^{4} 3.5 \% \mathrm{FCM}=$ milk weight $+[16.425 \times($ milk fat $/ 100) \times$ milk weight $]$} \\
\hline \multicolumn{5}{|c|}{${ }^{5}$ Energy-corrected milk $=(0.3246 \times \mathrm{kg}$ milk $)+(12.86 \times \mathrm{kg}$ fat $)+$} \\
\hline
\end{tabular}

creased milk production can often be traced to the interference of fat with ruminal fermentation or to poor digestibility of fatty acids (NRC, 2001). The diversion of energy to fat stores rather than to milk formation does occur, but it is physiologically less common in healthy, high-producing cows. Milk fat depression occurs when rations are high in added fat, especially when all dietary sources are from plant origin (NRC, 2001). In this experiment, cows fed ground canola seed did not exhibit a depression in milk component yield, despite the fact that all of the added fat was from canola seed.

Inclusion of fat supplements in the ration of lactating ruminants has also been shown to reduce the protein content of milk. Delbecchi et al. (2001) found that milk protein yield tends to be lower in cows fed canola seed when compared with milk from cows fed $4.8 \%$ formaldehyde-protected canola seed. Jahreis and Richter (1994) reported a 10\% decrease in milk protein of cows fed 5.5\% (of diet DM) ground canola seed. Baumgard et al. (2000) found that during 4-d infusions of a trans-10,cis-12 CLA supplement, milk yield and milk protein were not altered, although milk protein content was slightly reduced. Even though intake tended to be lower during the infusion, DM intake was similar for all treatments in this Latin square-design experiment. Therefore, dietary canola seed, which is high in polyunsaturated fatty acids (PUFA), likely contributed to the lower milk protein percentage of GCS cows in the present experiment.
According to Johnson et al. (2002), it is common for cows fed rations containing oilseed to have increased levels of MUN and BUN, likely the result of increased nitrogen absorption across the ruminal wall. In our study the GCS cows received a diet that was similar in $\mathrm{CP}$ but higher in $\mathrm{NE}_{\mathrm{L}}$ (Table 1) than the CON cows; therefore, the milk from GCS cows had lower MUN $(P$ $<0.01)$ and tended to have lower BUN $(P<0.08)$. The difference in MUN may be the result of decreased AA delivery to the small intestine. In dairy cows, urea nitrogen found in blood and milk reflects the catabolism of protein by ruminant tissues and catabolism of protein within the rumen by bacteria (Linn and Olson, 1995). Hussein et al. (1996) found that crushed canola seed, fed at 5\% dietary DM, did not affect ruminal nitrogen metabolism or flow of AA to the duodenum.

The effect of fatty acids on insulin release is dependent both on chain length and the degree of unsaturation in the ration (Opara et al., 1994). The serum measures of glucose ( 63.67 vs. $64.67, P=0.63)$ and insulin (6.5 vs. $7.5, P=0.41$ ) for CON vs. GCS cows, respectively, were not affected by diet. There was no difference among weeks or an interaction between week and treatment (data not shown). Delbecchi et al. (2001) similarly reported no differences for insulin in cows fed diets that compared canola meal and canola seed. Levels of dietary long-chain fatty acids in that experiment were similar to those in the current study.

Serum NEFA can be used as an effective monitor of adipose tissue lipolysis in the dairy cow, especially during periods of negative energy balance. However, cows in a positive energy balance should not be mobilizing large amounts of NEFA. According to Grummer (1993), fat supplementation also results in elevated NEFA through inefficient uptake of fat by peripheral tissues. Therefore, because serum NEFA were not different between the CON and GCS groups (206.21 vs. 196.31 , respectively, $P=0.75$ ), we contend that adding $3.9 \%$ (of diet DM) fat from ground canola seed did not affect use of nutrients.

Cows in the GCS group had higher serum triglycerides than CON cows ( $P=0.01$; Table 4$)$. According to LaCount et al. (1994), the concentration of triglycerides in serum increases when cows receive increasing levels of dietary fatty acids from canola seed. Bacteria and protozoa in the rumen hydrolyze complex lipids into their constituent long-chain fatty acids, sugars, organic bases, and glycerol. Thus, the rumen is the primary site of complex lipid hydrolysis rather than the small intestine. The glycerol and sugars are fermented to VFA. In contrast, unsaturated fatty acids are hydrogenated to saturated fatty acids. Small amounts of trans isomers and CLA escape biohydrogenation in the rumen and are absorbed in the small 
Table 5. Fatty acid composition of milk fat for lactating dairy cows fed a diet containing 14\% (of diet DM) ground canola seed. ${ }^{1}$

\begin{tabular}{|c|c|c|c|c|}
\hline Fatty acid & $\mathrm{CON}$ & GCS & $\mathrm{SEM}^{2}$ & $P^{3}$ \\
\hline & \multicolumn{4}{|c|}{$\mathrm{g} / 100 \mathrm{~g}$ of fatty acid } \\
\hline $\mathrm{C}_{4: 0}$ & 2.66 & 2.54 & 0.04 & 0.04 \\
\hline $\mathrm{C}_{6: 0}$ & 1.58 & 1.29 & 0.03 & 0.001 \\
\hline $\mathrm{C}_{8: 0}$ & 1.09 & 0.79 & 0.03 & 0.001 \\
\hline $\mathrm{C}_{10.0}$ & 2.74 & 1.76 & 0.12 & 0.001 \\
\hline $\mathrm{C}_{12: 0}$ & 3.28 & 2.11 & 0.14 & 0.001 \\
\hline $\mathrm{C}_{14: 0}$ & 11.07 & 8.51 & 0.29 & 0.001 \\
\hline $\mathrm{C}_{16: 0}$ & 28.36 & 22.18 & 0.49 & 0.001 \\
\hline $\mathrm{C}_{16: 1}$ & 1.98 & 1.53 & 0.057 & 0.001 \\
\hline $\mathrm{C}_{18: 0}$ & 12.94 & 18.55 & 0.52 & 0.001 \\
\hline $\mathrm{C}_{18: 1}$ & 28.36 & 35.37 & 0.51 & 0.001 \\
\hline $\mathrm{C}_{18: 1}$ trans-11 vaccenic acid (TVA) & 0.95 & 1.14 & 0.048 & 0.01 \\
\hline $\mathrm{C}_{18: 2}$ & 1.72 & 1.72 & 0.043 & 0.94 \\
\hline $\mathrm{C}_{18: 2}$ cis-9,trans-11 conjugated linoleic acid (CLA) & 0.35 & 0.39 & 0.016 & 0.12 \\
\hline $\mathrm{C}_{18: 2}$ trans-10,cis-12 CLA & 0.004 & 0.003 & 0.001 & 0.18 \\
\hline Total CLA isomers & 0.386 & 0.421 & 0.016 & 0.15 \\
\hline $\mathrm{C}_{18: 3} \mathrm{n}-6$ & 0.47 & 0.52 & 0.014 & 0.02 \\
\hline $\mathrm{C}_{20: 0}$ & 0.17 & 0.27 & 0.08 & 0.001 \\
\hline $\mathrm{C}_{20: 2}$ & 0.077 & 0.059 & 0.002 & 0.003 \\
\hline $\mathrm{C}_{22: 1}^{20.2}$ & 0.025 & 0.021 & 0.004 & 0.53 \\
\hline $\mathrm{C}_{22: 5}$ & 0.069 & 0.069 & 0.003 & 0.88 \\
\hline $\mathrm{C}_{24: 0}$ & 0.042 & 0.041 & 0.002 & 0.78 \\
\hline Short chain $\left(\mathrm{C}_{4: 0}\right.$ to $\left.\mathrm{C}_{12: 0}\right)$ & 11.37 & 8.50 & 0.32 & 0.001 \\
\hline Medium chain $\left(\mathrm{C}_{14: 0}\right.$ to $\left.\mathrm{C}_{17: 0}\right)$ & 44.18 & 34.30 & 0.69 & 0.001 \\
\hline Long chain $\left(\geq \mathrm{C}_{18: 0}\right)$ & 44.41 & 57.12 & 0.87 & 0.001 \\
\hline$n-3$ & 0.54 & 0.64 & 0.029 & 0.02 \\
\hline$n-6$ & 2.23 & 2.09 & 0.045 & 0.04 \\
\hline n-6:n-3 & 4.17 & 3.47 & 0.069 & 0.001 \\
\hline $\mathrm{C}_{16: 1}: \mathrm{C}_{16: 0}$ & 0.07 & 0.06 & 0.002 & 0.59 \\
\hline $\mathrm{C}_{18: 1}: \mathrm{C}_{18: 0}$ & 2.20 & 1.95 & 0.05 & 0.004 \\
\hline $\mathrm{C}_{18: 2}$ (CLA): $\mathrm{C}_{18: 1}$ (TVA) & 0.37 & 0.34 & 0.009 & 0.02 \\
\hline Total, $\mu \mathrm{g} / \mathrm{mg}$ of fat & 230.5 & 234.4 & 8.91 & 0.76 \\
\hline
\end{tabular}

${ }^{1} \mathrm{CON}=$ Control; GCS $=$ ground canola seed treatment.

${ }^{2}$ Standard error of the mean, $\mathrm{n}=12$.

${ }^{3}$ Probability, significance level of $F$-test for equality.

intestine and available for incorporation as preformed unsaturated fatty acids in the bovine mammary gland (LaCount et al., 1994). Therefore, higher serum triglyceride levels indicate that the epithelium of the small intestine is capable of absorbing the dietary fatty acids postruminally and incorporating them into triglyceride lipoproteins. In the present study, serum triglycerides remained higher for cows in the GCS group throughout the experiment, both increasing for the first $6 \mathrm{wk}$ (data not shown) and then remaining at that level for the duration of the experiment.

\section{Fatty Acid Composition of Feed and Milk}

The fatty acid profile of milk fat was altered with canola seed supplementation (Table 5). Feeding ground canola seed reduced $(P=0.001)$ the proportion of both short-chain $\left(\mathrm{C}_{4: 0}\right.$ to $\left.\mathrm{C}_{12: 0}\right)$ and medium-chain $\left(\mathrm{C}_{14.0}\right.$ to $\left.\mathrm{C}_{17.1}\right)$ fatty acids, and increased $(P=0.001)$ the proportion of long-chain $\left(\geq \mathrm{C}_{18: 0}\right)$ fatty acids in milk fat. These results agree with those reported by Aldrich et al. (1997) who used canola seed. Short-chain fatty acids are mainly synthesized in the epithelial cells of the mammary gland of the dairy cow, and their synthesis is susceptible to inhibition when increasing dietary levels of certain long-chain fatty acids. The trans double bond in trans fatty acids originates only from bacterial fermentation and increases substantially in cows fed diets that are high in PUFA without depressing milk fat percent, assuming balanced diets containing adequate forage (Kalscheur et al., 1997; Bauman et al., 1999).

The specific positional isomer of the trans fatty acid double bond produced during ruminal fermentation is important. The review by Bauman et al. (1999) reported that milk fat depression occurs only when the trans-10 $\mathrm{C}_{18: 1}$ isomer is increased as compared with normal situations where the trans- $11 \mathrm{C}_{18: 1}$ isomer is the most abundant. The medium-chain fatty acid palmitate can be derived from the ration, or it can be synthesized in the mammary gland. The canola seed used in the GCS ration contained less $\mathrm{C}_{16: 0}$, so as ex- 
pected, the concentration of $\mathrm{C}_{16: 0}$ in milk fat of GCS cows was lower $(P=0.001)$ than in milk fat of CON cows (Table 5). Lowering $\mathrm{C}_{14: 0}$ and $\mathrm{C}_{16: 0}$ in milk fat by supplementing dairy cow rations with long-chain unsaturated fatty acids is touted to add health benefits to dairy products. Our results produced similar changes in the fatty acid profile and therefore are congruent with scientific efforts to improve the nutrient value of dairy products.

Milk fat contains fatty acids derived from de novo synthesis by the mammary gland and from mammary uptake of preformed fatty acids. Recent evidence suggests that certain transient intermediates in the biohydrogenation of PUFA potently inhibit endogenous fatty acid synthesis in the mammary gland. On a molar basis, approximately $80 \%$ of the reduction in milk yield of fatty acids is accounted for by the reduction in de novo synthesis of fatty acids when cows received a mixture of CLA isomers (Chouinard et al., 1999). The trans-10,cis-12 CLA isomer has been identified as having a potent effect on milk fat synthesis in lactating cows (Baumgard et al., 2000). Milk fat from GCS cows tended to be lower $(P<0.18)$ in the trans-10,cis-12 CLA isomer than that from CON cows. Piperova et al. (2000) reported that in cows fed a high-grain, lowforage diet that contained soybean oil $(5.0 \% \mathrm{DM})$, the increases in trans-10 $\mathrm{C}_{18: 1}$ and trans-10,cis-12 CLA in milk fat were associated with significantly lower levels of de novo synthesized fatty acids. In the present study, based on the fatty acid composition of milk fat and ruminal fermentation characteristics, it is unclear why milk fat percentage was reduced when adding ground canola seed to the diet.

The concentration of $\mathrm{C}_{18: 0}$ in milk fat from GCS cows was approximately $43 \%$ greater $(P=0.001)$ than that from CON cows (Table 5). This may be related to the lower level of $\mathrm{C}_{18: 0}$ in the $\mathrm{CON}$ ration, the higher levels of unsaturated $\mathrm{C}_{18}$ fatty acids in the GCS ration, or both (Table 2). We found that feeding ground canola seed (14\% of diet DM; $34 \%$ lipid) increased $\mathrm{C}_{18: 1}$ in milk by nearly $25 \%$ (from 28.36 to $35.37 \mathrm{~g} / 100 \mathrm{~g}$ of milk fat) $(P=0.001$; Table 5$)$, whereas Aldrich et al. (1997) found more pronounced results from feeding ground canola seed (11.2\% of diet DM; $55 \%$ lipid), where the total $\mathrm{C}_{18: 1}$ content in milk was increased $67 \%$ (from 20.1 to $33.6 \mathrm{~g} / 100 \mathrm{~g}$ of milk fat). The differences in the proportion of $\mathrm{C}_{18: 1}$ in milk fat between CON and GCS in the current study could be attributed to rapid availability of oil in the rumen and its potential to reduce fiber digestibility or to the higher dietary proportion of forage in our study when compared with the Aldrich et al. (1997) study.

In the present study, the addition of canola seed to lactation rations increased the concentration of $\mathrm{C}_{18: 3}$
$(P=0.02)$ in milk fat, but it did not alter $\mathrm{C}_{18.2}$ despite higher levels of $\mathrm{C}_{18: 2}$ in the diet. This is likely the result of hydrolysis and hydrogenation of $\mathrm{C}_{18: 2}$ by ruminal microorganisms (Murphy et al., 1990). Dietary canola seed increased the PUFA proportion of n-3 $(P=0.02)$ and decreased the proportion of $\mathrm{n}-6(P=0.04$; Table $5)$, thereby lowering the n-6 to n-3 fatty acid ratio $(P=$ 0.001). Reducing the ratio of $n-6$ to $n-3$ fatty acids increases cell membrane fluidity and functionality, and is important for membrane activity at the site of hormone receptors in humans (Kremer et al., 1987).

The cis-9,trans-11 CLA isomer typically represents more than $90 \%$ of the total CLA present in milk fat (Bauman et al., 1999). The concentration of this isomer tended to be higher in milk fat from GCS cows $(P=$ 0.12; Table 5) as did the concentration of total CLA isomers which included cis-9,trans-11; trans-10,cis-12; and trans-7,cis-9 $(P=0.15$; Table 5). Our reported CLA concentrations $(0.42 \mathrm{~g} / 100 \mathrm{~g}$ of fatty acid) were lower than those reported by Dhiman et al. (1999) who used full-fat extruded soybeans $(0.6 \mathrm{~g} / 100 \mathrm{~g}$ of fatty acid). This may be a consequence of the lower than typical fat content (usually 50 to 55\%) in the canola seed used in this study (34\%), or, more likely, oil released from the mechanical grinding of canola seed is not as readily available as oil from the process of extrusion, thus affecting subsequent availability of the oil to ruminal microbes. The increase in milk PUFA suggests a portion of canola seed oil escaped ruminal metabolism and saturation. Despite the lower metabolic efficiency and the additional steps required to produce the CLA precursor of TVA from $\mathrm{C}_{18: 3}$ (Bauman et al., 1999), the lower level of $\mathrm{C}_{18: 3}$ in the GCS ration (Table 2) may have contributed to the magnitude of difference in the levels of TVA and CLA between treatments.

The changes in cis-9,trans-11 CLA exhibited a time $\times$ treatment interaction (Figure 1), even though the same lot of forage was procured and stored under cover for both experiments. Actual milk yield patterns (data not shown) fluctuated similarly to the rise and fall of cis-9,trans-11 CLA concentrations in milk fat over time; a decline in milk yield (data not shown) was evident at wk 4 for both treatments, but a 2 -fold greater decline in milk yield was noteworthy for CON vs. GCS cows. Given that the yield of milk fat was similar between treatments $(P=0.27)$ and similar across time for the experiment $(P=0.75)$, the explanation for the milk yield pattern is not readily apparent.

The predominant fatty acid isomer produced from ruminal biohydrogenation is trans- $\mathrm{C}_{18: 1}$ TVA (Baumgard et al., 2000). The concentration of TVA in milk fat from GCS cows was increased by $20 \%$ over that in milk fat from CON cows $(P=0.01$; Table 5$)$. Increasing milk TVA is beneficial because tissues in humans as well 

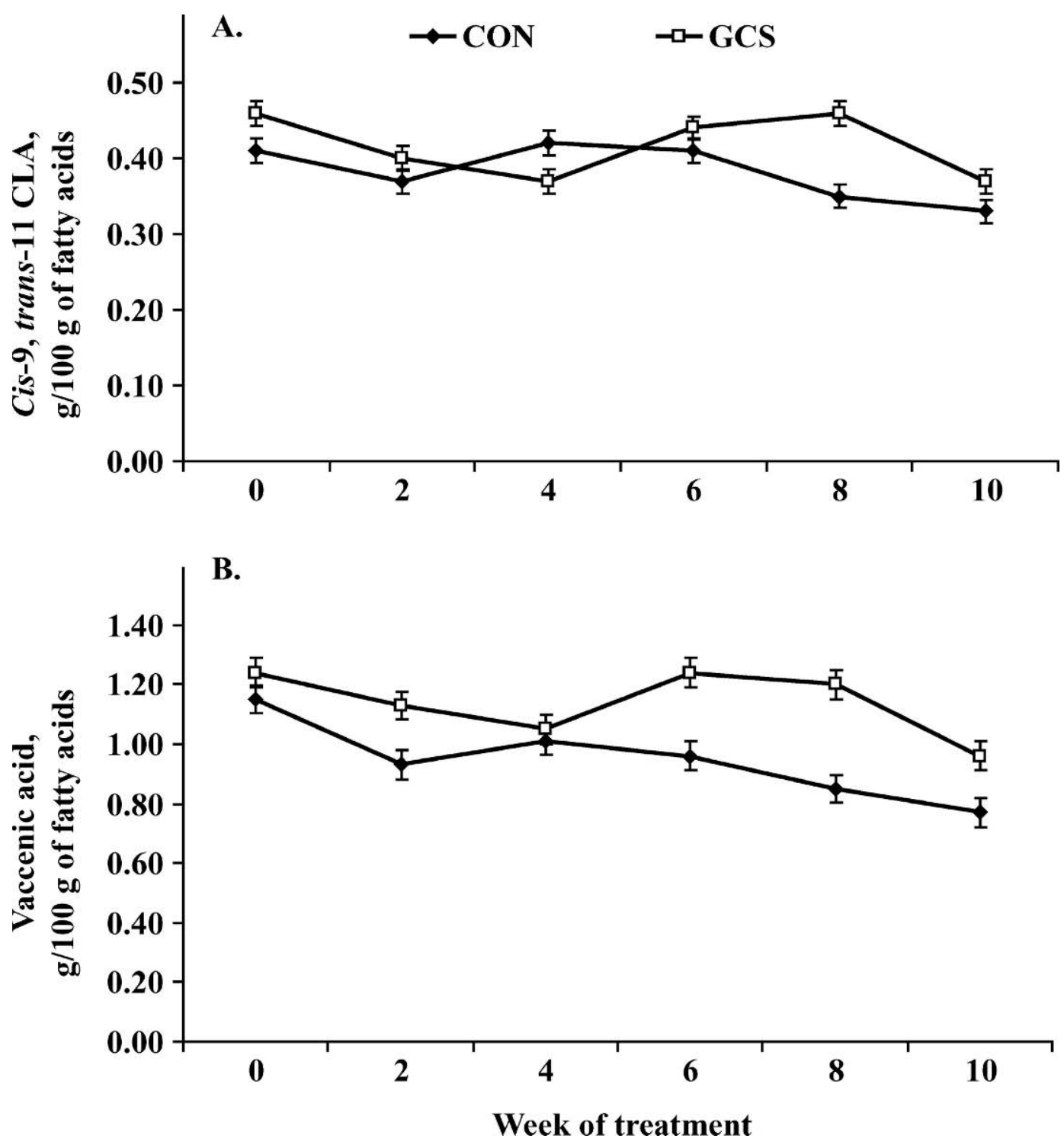

Figure 1. Temporal patterns of milk fat for lactating dairy cows fed a diet containing $14 \%$ (of diet DM) ground canola seed. CON = Control; GCS = ground canola seed treatment. Values are means, $\mathrm{n}=12$. A) Cis-9,trans-11 conjugated linoleic acid (CLA). Effects of treatment: wk $0(P=0.18)$, wk $2(P=0.48)$, wk $4(P=0.30)$, wk $6(P=0.36)$, wk $8(P=0.004)$, and wk $10(P=0.27)$. A treatment $\times$ week interaction was observed $(P=0.05)$. B) Vaccenic acid. Effects of treatment: wk $0(P=0.38)$, wk $2(P=0.06)$, wk $4(P=0.72)$, wk $6(P=0.008)$, wk 8 $(P=0.001)$, and wk $10(P=0.07)$. No treatment $\times$ week interaction was detected $(P=0.12)$.

as in the bovine can synthesize cis-9,trans-11 CLA from TVA via $\Delta^{9}$-desaturase (Salminen et al., 1998). There are 3 pairs of fatty acids in milk fat that represent a product-to-substrate ratio for $\Delta^{9}$-desaturase; their ratio in milk fat can serve as a proxy for the presence or activity of this enzyme in the mammary gland (Bauman et al., 1999). Referred to as desaturase index, these ratios include $\mathrm{C}_{16: 1}: \mathrm{C}_{16: 0}, \mathrm{C}_{18: 1}: \mathrm{C}_{18: 0}$, and $\mathrm{C}_{18: 2}$ cis-9,trans-11 (CLA): $\mathrm{C}_{18: 1}$ trans-11 (TVA). A lower ratio of product-to-substrate indicates lower $\Delta^{9}$-desaturase activity. In a review, Bauman et al. (1999) re- ported that these ratios are reduced in milk fat when cows receive CLA in the presence of $\mathrm{C}_{18: 2}$ trans-10, cis12. In this study, there was an indication of reduced $\Delta^{9}$-desaturase activity in GCS cows given the ratios of these fatty acids (Table 5) $(P=0.004$ and $P=0.02$, for $\mathrm{C}_{18: 1}: \mathrm{C}_{18: 0}$ and CLA:TVA, respectively). In addition, the proportion of TVA in milk fat from GCS cows followed the same temporal pattern as that of CLA (Figure 1), but unlike CLA, the treatments were different except for measures taken at wk 4. A precursor-toproduct relationship may exist between TVA and CLA 
at the tissue level, and endogenous synthesis of CLA is likely (Corl et al., 2001).

\section{CONCLUSIONS}

The results show that $3.9 \%$ added fat from ground canola seed for a total of $6.4 \%$ dietary fat (DM basis) to lactating cow diets favorably altered the fatty acid profile in milk fat. The changes in fatty acid profile were not associated with reduced milk yield or composition. Adding ground canola seed to the diets of lactating dairy cows resulted in an increase in the proportions of $\mathrm{C}_{18}$ monounsaturated fatty acids including TVA, and isomers of CLA in milk fat. Milk from GCS cows had lower proportions of short- and mediumchain fatty acids (25 and $22 \%$ ), respectively, increased proportions of several long-chain fatty acids (28\%), and increased concentrations of n-3 fatty acids (19\%). Nutraceutical implications of consuming products high in $\mathrm{n}-3$ fatty acids have been identified. Dietary microcomponents such as CLA can have positive effects on human health and disease prevention beyond those associated with traditional nutritive values. Improved wellness by adding functionality to milk has the potential to increase its demand in the future.

\section{ACKNOWLEDGMENTS}

The authors express their appreciation for the hours of support contributed by the Dairy Research Center staff and expertise provided by the nutrition laboratory technicians. This research was funded through a grant from the North Dakota State Board of Agricultural Research and Education (SBARE).

\section{REFERENCES}

Aldrich, C. G., N. R. Merchen, J. K. Drackley, G. C. Fahey, Jr., and L. L. Berger. 1997. The effects of chemical treatment of whole canola seed on intake, nutrient digestibilities, milk production, and milk fatty acids of Holstein cows. J. Anim. Sci. 75:512-521.

Aminot-Gilchrist, D. V., and H. D. I. Anderson. 2004. Insulin resistance-associated cardiovascular disease: Potential benefits of conjugated linoleic acid. Am. J. Clin. Nutr. 79(Suppl. 6):1159S-1163S.

AOAC. 1997. Official Methods of Analysis. 16th ed., 3rd rev. Association of Official Analytical Chemists International, Gaithersburg, MD.

Bauman, D. E., L. H. Baumgard, B. A. Corl, and J. M. Griinari. 1999. Biosynthesis of conjugated linoleic acid in ruminants. Proc. Am. Soc. Anim. Sci. Online. Available http://www.asas.org/jas/ symposia/proceedings/0937.pdf. Accessed Nov. 1, 2003.

Baumgard, L. H., B. A. Corl, D. A. Dwyer, A. Sæbø, and D. E. Bauman. 2000. Identification of the conjugated linoleic acid isomer that inhibits milk fat synthesis. Am. J. Physiol. Regul. Integr. Comp. Physiol. 278:R179-184.

Chaney, A. L., and E. P. Marbach. 1962. Modified reagents for determination of urea and ammonia. Clin. Chem. 8:130-132.

Chouinard, P. Y., L. Corneau, A. Sæbø, and D. E. Bauman. 1999. Milk yield and composition during abomasal infusion of conjugated linoleic acids in dairy cows. J. Dairy Sci. 82:2737-2745.
Corl, B. A., L. H. Baumgard, D. A. Dwyer, J. M. Griinari, B. S. Phillips, and D. E. Bauman. 2001. The role of $\Delta^{9}$-desaturase in the production of cis-9, trans-11 CLA. J. Nutr. Biochem. 12:622-630.

Delbecchi, L., C. E. Ahnadi, J. J. Kennelly, and P. Lacasse. 2001. Milk fatty acid composition and mammary lipid metabolism in Holstein cows fed protected or unprotected canola seeds. J. Dairy Sci. 84:1375-1381.

Dhiman, T. R., E. D. Helmink, D. J. McMahon, R. L. Fife, and M. W. Pariza. 1999. Conjugated linoleic acid content of milk and cheese from cows fed extruded oilseeds. J. Dairy Sci. 82:412-419.

Dirksen, G., and M. C. Smith. 1987. Acquisition and analysis of bovine rumen fluid. Bovine Pract. 22:108-116.

Erwin, E. S., G. J. Marco, and E. M. Emery. 1961. Volatile fatty acid analyses of blood and rumen fluid by gas chromatography. J. Dairy Sci. 44:1768-1771.

Farrance, I. 1987. Plasma glucose methods, a review. Clin. Biochem. Rev. 8:55-68.

Folch, J., M. Lees, and G. H. Sloane Stanley. 1957. A simple method for the isolation and purification of total lipids from animal tissues. J. Biol. Chem. 226:497-509.

Fossati, P., and L. Prencipe. 1982. Serum triglycerides determined colorimetrically with an enzyme that produces hydrogen peroxide. Clin. Chem. 28:2077-2080.

Gaullier, J. M., J. Halse, K. Hoye, K. Kristiansen, H. Fagertun, H. Vik, and O. Gudmundsen. 2004. Conjugated linoleic acid supplementation for $1 \mathrm{y}$ reduces body fat mass in healthy overweight humans. Am. J. Clin. Nutr. 79:1118-1125.

Grummer, R. R. 1993. Etiology of lipid-related metabolic disorders in periparturient dairy cows. J. Dairy Sci. 76:3882-3896.

Hussein, H. S., N. R. Merchen, and G. C. Fahey, Jr. 1996. Effects of forage percentage and canola seed on ruminal protein metabolism and duodenal flows of amino acids in steers. J. Dairy Sci. 79:98-104.

Jahreis, G., and G. H. Richter. 1994. The effect of feeding rapeseed on the fatty-acid composition of milk lipids and on the concentration of metabolites and hormones in the serum of dairy cows. J. Anim. Physiol. Anim. Nutr. 72:71-79.

Jeevanandam, M., Y. C. Hsu, L. Ramias, and W. R. Schiller. 1989. A rapid, automated micromethod for measuring free fatty acids in plasma/serum. Clin. Chem. 35:2228-2231.

Johnson, K. A., R. L. Kincaid, H. H. Westberg, C. T. Gaskins, B. K. Lamb, and J. D. Cronrath. 2002. The effect of oilseeds in diets of lactating cows on milk production and methane emissions. J. Dairy Sci. 85:1509-1515.

Kalscheur, K. F., B. B. Teter, L. S. Piperova, and R. A. Erdman. 1997. Effect of fat source on duodenal flow of trans $-\mathrm{C}_{18: 1}$ fatty acids and milk fat production in dairy cows. J. Dairy Sci. 80:2115-2126.

Khorasani, G. R., G. de Boer, P. H. Robinson, and J. J. Kennelly. 1992. Effect of canola fat on ruminal and total tract digestion, plasma hormones, and metabolites in lactating dairy cows. J. Dairy Sci. 75:492-501.

Kremer, J. M., W. Jubiz, A. Michalek, R. I. Rynes, L. E. Bartholomew, J. Bigaouette, M. Timchalk, D. Beeler, and L. Lininger. 1987. Fish-oil fatty acid supplementation in active rheumatoid arthritis. A double-blinded, controlled, crossover study. Ann. Intern. Med. 106:497-503.

LaCount, D. W., J. K. Drackley, S. O. Laesch, and J. H. Clark. 1994. Secretion of oleic acid in milk fat in response to abomasal infusions of canola or high oleic sunflower fatty acids. J. Dairy Sci. 77:1372-1385.

Linn, J. G., and J. D. Olson. 1995. Using milk urea nitrogen to evaluate diets and reproductive performance of dairy cattle. Pages 155-167 in 4-State Appl. Nutr. Management Conf., LaCrosse, WI. Univ. of Wisconsin, Madison, WI.

Littell, R. C., G. A. Milliken, S. W. Walter, and R. D. Wolfinger. 1996. SAS Systems for Mixed Models, SAS Inst., Inc., Cary, NC.

Marschner, I., P. Bottermann, F. Erhardt, R. Linke, G. Loffler, V. Maier, P. Schwandt, W. Vogt, and P. C. Scriba. 1974. Group experiments on the radioimmunological insulin determination. Horm. Metab. Res. 6:293-296. 
McGowan, M. W., J. D. Artiss, D. R. Strandbergh, and B. Zak. 1983. A peroxidase-coupled method for the colorimetric determination of serum triglycerides. Clin. Chem. 29:538-542.

Murphy, J. J., G. P. McNeill, J. F. Connolly, and P. A. Gleeson. 1990. Effect on cow performance and milk fat composition of including full fat soyabeans and rapeseeds in the concentrate mixture for lactating cows. J. Dairy Res. 57:295-306

NRC. 2001. Nutrient Requirements of Dairy Cattle. 7th rev. ed. Natl. Acad. Sci., Washington, DC.

Opara, E. C., M. Garfinkel, V. S. Hubbard, W. M. Burch, and O. E. Akwari. 1994. Effect of fatty acids on insulin release: Role of chain length and degree of unsaturation. Am. J. Physiol. Endocrinol. Metab. 266:E635-E639.

Park, P. W., and R. E. Goins. 1994. In situ preparation of fatty acid methyl esters for analysis of fatty acid composition in foods. J. Food Sci. 59:1262-1266.

Piperova, L. S., B. B. Teter, I. Bruckental, J. Sampugna, S. E. Mills, M. P. Yurawecz, J. Fritsche, K. Ku, and R. A. Erdman. 2000.
Mammary lipogenic enzyme activity, trans fatty acids and conjugated linoleic acids are altered in lactating dairy cows fed a milk fat-depressing diet. J. Nutr. 130:2568-2574.

Salminen, I., M. Mutanen, M. Jauhiainen, and A. Aro. 1998. Dietary trans fatty acids increase conjugated linoleic acid levels in human serum. J. Nutr. Biochem. 9:93-98.

Schauff, D. J., and J. H. Clark. 1992. Effects of feeding diets containing calcium salts of long-chain fatty acids to lactating dairy cows. J. Dairy Sci. 75:2990-3002.

Van Soest, P. J., J. B. Robertson, and B. A. Lewis. 1991. Methods for dietary fiber, neutral detergent fiber, and nonstarch polysaccharides in relation to animal nutrition. J. Dairy Sci. 74:3583-3597.

Wildman, E. E., G. M. Jones, P. E. Wagner, R. L. Boman, H. F. Troutt, Jr., and T. N. Lesch. 1982. A dairy cow body condition scoring system and its relationship to selected production characteristics. J. Dairy Sci. 65:495-501. 